Arab World English Journal (AWEJ) Volume 12. Number4 December 2021

DOI: https://dx.doi.org/10.24093/awej/vol12no4.5

Pp.69-85

\title{
Cultural Component in Professional Development of Non-philological Specialties Students in the Process of Studying a Foreign Language
}

\author{
Zinaida Bakum \\ Department of Ukrainian Language, Faculty of Ukrainian Philology, Kryvyi Rih State Pedagogical University, \\ University, Kryvyi Rih, Ukraine
}

Iryna Savchak

Department of Foreign Languages and Translation, Faculty of History, Politology and International Relations, Vasyl Stefanyk Precarpathian National University, Ivano-Frankivsk, Ukraine

\section{Svitlana Kostiuk}

Department of Foreign Languages, Faculty of Information Technologies, Kryvyi Rih National University, Kryvyi

Rih, Ukraine

Corresponding Author: skostyukss@gmail.com

\begin{abstract}
Marianna Zhumbei
Department of Foreign Languages and Country Studies, Faculty of Tourism, Vasyl Stefanyk Precarpathian National University, Ivano-Frankivsk, Ukraine

Roman Poznanskyy

Department of Foreign Languages and Country Studies, Faculty of Tourism, Vasyl Stefanyk Precarpathian National University, Ivano-Frankivsk, Ukraine
\end{abstract}

Received: 7/20/2021

Accepted: $11 / 3 / 2021$

Published: $12 / 15 / 2021$

\section{Abstract}

The professional development of future specialists has to meet global and domestic standards. Cultural competence is essential for future professionals as it makes it easier to collaborate with foreign professionals, improve their competitiveness in the world labor market and increase the specialist's ability to solve professional challenges. The study attempts to answer the questions about the importance of cultural competence development of nonphilological students in the process of studying a foreign language and methodological approaches used in this process. The aim of the paper is to present the model of cultural competence formation of future non-philological specialties experts at the foreign languages classes and determine its main components and formation conditions. The study investigates how cultural competence development changes the value-based attitude towards future professional activity and promotes the interest in learning, personal and professional enrichment. Students of three Ukrainian higher educational institutions (from the first to third course) have taken part in the research. The research used conscious-comparative, audiolingual, and role-play methods. The study of the results, based on four criteria (cognitive, moral-axiological, communicative, cultural), showed that learners started to understand the necessity of cultural enrichment of disciplines. The research proved that the implementation of the given technique resulted in the improvement of students' learning and cognitive activity and enhancement of the general level of training. The paper gives some recommendations for language teachers to organize the process of learning a language on a cultural basis.

Keywords: Competence approach, cultural competence, cultural component, foreign language, non-philological students, professional development, quality of training

Cite as: Bakum, Z., Savchak, I., Kostiuk, S., Zhumbei, M. \& Poznanskyy, R. (2021). Cultural Component in Professional Development of Non-philological Specialties Students in the Process of Studying a Foreign Language. Arab World English Journal, 12 (4) 69-85. DOI: https://dx.doi.org/10.24093/awej/vol12no4.5 


\section{Introduction}

Intensification of globalization processes at the beginning of the XXI century, mutual influence, and interaction of different cultural communities made intercultural communication an integral part of the harmonious existence of organizations, establishments, and individuals. The changes faced by modern society trigger cultural transformation (relationship between people, formation of new cultural values and norms, etc.). Nowadays, according to the requirements of the specialists' quality of training, professional education trains specialists taking into account competence, humanistic and cultural aspects.

Economic, political, scientific, social interaction between countries requires a great number of effort. Therefore, in the view of the world-leading organizations, the crucial tasks of education are: to facilitate learning of other nations' language, culture, history, improvement of mutual understanding and cultural interaction (The Council of Europe Contribution, 2019); to focus on educational process on the development of mutual respect, tolerance, friendship among nations, racial and religious groups and peacekeeping (UNESCO Guidelines on Intercultural Education, 2006); to overcome communication barriers, to turn cultural and language diversity from communication obstacles into a source of cross-fertilization and mutual understanding (Common European Framework, 2001).

The necessity to correspond current requirements in the sphere of intercultural communication and collaboration emphasizes the importance of developing the standards of higher education and put in place a system of professional training that correlates to European demands for higher education.

The analysis of adopted standards of higher education for different specialties proves that the ability to use foreign languages to solve communicative tasks in different spheres of activity, ability to keep and multiply moral, cultural, scientific values, and society's achievements are among the key features of a specialist (Standards of Higher Education of Ukraine, 2019).

World and domestic standards of higher education facilitate changes in the professional training of non-philological specialties students. Needless to say that nowadays, the development of professional and general culture, soft skills, communicative skills, intercultural knowledge is as important as hard skills development. So, the aim of professional training is to prepare a person for professional activity in a specific area of industry and for harmonious interaction in a multicultural world as well.

The world's population is multinational, so it is vital to develop cultural components in education to improve mutual understanding.

Current globalization processes in society amid the mass media extension where emotions prevail over the sense, situational knowledge over logical one, behavioral skills over intelligent conscious behavior, have resulted in changes in thinking and the system of values became the reason of culture isolation from professional activities. The researchers put emphasis upon the necessity to expand the cultural component in education, to construct the educational process on the basis of human values (Kochneva et al., 2018). 
The professional development of future specialists has to meet global and domestic standards. The ability to collaborate with specialists from other countries, be competitive in the world labor market, solve professional challenges is significant for future professionals. Therefore, the development of cultural competence in the process of learning foreign languages is essential.

The aim of the paper is to present the model of cultural competence formation of future nonphilological specialties experts at the foreign languages classes and determine its main components and formation conditions.

To identify the problem and find a solution to it, the current study attempted to answer the following questions:

1. What are the main methodological approaches used in the professional development of non-philological specialties students in the process of studying a foreign language?

2. Why is it essential to develop the cultural competence of non-philological students while learning a foreign language?

The objectives of the research are the following: to analyze the essence of the term "cultural competence", characterize its key components, analyze the factors which affect the formation of cultural competence, to develop and test the effectiveness of the cultural competence formation technique.

\section{Literature Review}

\section{Competence Approach in the Process of Professional Development}

Global processes of education modernization have promoted such credible international organizations in the field of education as the UNO, UNESCO, UNICEF, UNDP, the Council of Europe, etc. to implement the project "Educational policy and peer-to-peer education". Based on the analysis of specialists' training efficiency and effectiveness in different countries, the experts of these organizations offered a competence approach that transforms traditional models of education from informative and procedural to effective.

It is thought that implementation of competence approach allows to form self-motivated, selfsufficient, and responsible members of society that will acquire not only thorough knowledge but skills to use it, solve professional and social tasks and accept the consequences as well (Panfilov \& Furmanets, 2017); develop key competencies in intellectual, communicative, information, social, and other spheres (Palamar, 2018; Kovalchuk \& Fedorchenko, 2018). It is characterized by the versatility of the methods and by a wide range of activities that replace the traditional lecture-based courses, for case studies and scenario-based teaching (Ait Haddouchane et al., 2017).

The ultimate goal of competence approach implementation, according to Palamar (2018), is to develop skills that allow a personality to integrate into the social and cultural space: understanding of the essence of a human, the relationship between a person and nature; understanding the uniqueness of culture and mechanism of interaction; ability to cooperate in the context of dialogue of culture; ability to choose the appropriate sources of information, understand the variety of decisions, and solve tasks in different spheres (social and professional); ability to navigate in key issues of current life such as environmental, political, intercultural cooperation. 


\section{Cultural Component of Education}

The analysis of the main features of the competence approach allows concluding that the development of such personal traits as tolerance, awareness of belonging to the world culture, usage of language and culture for active dialogue with representatives of other nationalities is one of the major challenges of education. Hence, the development of cultural competence is of high importance.

Both foreign and domestic scientists emphasize on the importance of the cultural component of education. Issues of dialogue of cultures are represented in the studies of Astafiev, Bakhtin, Bibler, Pomerants, Telychko (Telychko \& Kostiuk, 2019), Zyrianov. The development of the communicative culture of future specialists of different training programs is shown in the papers of Grynkova, Kolbina, Kopus, Puz, Vasyleva. The development of culture-universe competence in the sphere of professional education is studied in the works of Andrushchenko, Fakhrutdinov, Goncharenko, Gopalkrishnan, Hrechanyk (Hrechanyk, 2020), Ivanov, Myshyakova, Zagrebin, Ziaziun. The improvement of common culture arises from the necessity to develop future specialists' value professional orientation.

The key component of cultural competence is the concept of "culture". It is considered by culture experts, anthropologists, social scientists, psychologists. According to Bakum and Palchykova (2019) "culture" is a basis for experience interchange between individuals in all spheres of activities and a determining factor in the development of a single informational cultural pluralistic society. The scientists study the influence of culture on society in detail (Jeannotte, 2017), interrelation of culture, environment, and education (Ivanov, 2016), and prove that language being a cultural code of nation has a great influence on the understanding between people (Zyryanova \& Chesnokova, 2020). The reduction of cultural and educational levels is interconnected, so, the necessity to introduce the cultural component into the content of education is obvious (Fierro et al., 2018; Shutenko et al., 2018).

Studying the concept "culture" in multicultural aspect Melnyk (2016) determines it as a basis for communication and semantic argumentation of the goals of human activities. Culture provides the conditions for human self-fulfillment, develops the necessary patterns and norms of behavior, and facilitates social regulations.

The above-mentioned definition proves the possibility and necessity of social impact on the cultural level of future specialists to develop their value professional orientation while training at higher educational establishments. Therefore, the formation of cultural competence is the integral component of the effective educational process that helps to improve its quality.

According to Fedortsova (2016), cultural competence is the complex unit that comprises culture, value and motivational sphere, ability to use acquired knowledge during the process of professional activity, ability to navigate in a multicultural environment, desire for selfdevelopment and self-education.

\section{Cultural Approach in the Professional Development of Non-philological Specialties Students}

Most studies that have explored the cultural component in education were concerned with the development of cultural competence separately from professional development. This study 
focused on the development of cultural and professional competencies that form the integral process of future specialists' formation.

Liddicoat \& Scrino (2013) argued that globalization processes such as mobility and technological development reshaped the understanding of communication and ways of interaction and brought the necessity of cultural development during language teaching and learning to the highest rank.

Slastonin (1997) emphasized the necessity to enrich the content of professional education with the cultural heritage of mankind which involves universal ideas, personal values and qualities, means of understanding and humanistic techniques of professional activity. Ukrainian scholar Blahodieitelieva-Vovk (2009) has proved the idea that one of the key factors of the society development is the ability to form two types of person - homo institutis and homo culturalis and modify the structure of the society in favor of these two types.

Studying the competences which are in demand in industry Modeer (1999) distinguished three key requirements for employees. She divided them in categories that involve knowledge, abilities and social competences. Among the latter the most important, according to the author, are cultural proficiency, communication skills and co-operation.

According to the scientists' research, in order to build a new advanced society, it is necessary to develop the universal culture of future specialists through the acquisition of knowledge of cultural achievements, understanding, and perception of universal human values. In contemporary reality, this process is impossible without mastering new means of cultural heritage storing, transformation, and transmission (Standards of higher education of Ukraine, 2019; Kochneva et al., 2018; Telychko \& Kostiuk, 2019; Hrechanyk, 2020).

Promoting such processes as self-understanding, self-concentration, self-fulfillment, search for new forms of experience, life activities individuals develop themselves, improve their strengths and skills, broaden communication boundaries, and form new needs and means of their fulfillment, namely, reveal the completeness of human existence.

Consequently, the involvement of an individual in culture is one of society's urgent tasks, which is possible to perform by means of education.

It is a well-known fact that education is one of the most important forms of cultural heritage accumulation and transmission which has peculiarities in every national culture. The developers of Standards of Higher Education of Ukraine focus on the importance of the formation of the capability to preserve and increase moral, cultural, scientific values and society's achievements based on the interpretation of history and laws of development of a subject area. This refers to cultural values in wide sense: scientific knowledge, professional skills and experience, achievements in art, moral standards and rules, standards and traditions of social behavior, etc.

Involving young people to social, cultural values and ideals, education promotes social order maintenance, whereas the implementation of new technologies and scientific rethinking of 
Arab World English Journal (AWEJ) Volume 12. Number 4. December 2021

Cultural Component in Professional Development

Bakum, Savchak, Kostiuk, Zhumbei \& Poznanskyy

existing knowledge facilitate social changes and social development. Therefore, education is a means of moral regulation and integration of society.

Taking into account all abovementioned, introduction of the cultural approach allows to analyse educational process through the prism of culture, develop a personality able to demonstrate individuality, acquire cultural competence and identify his / her position in the world of cultural values (Opachko, 2017; Bakum et al., 2019).

\section{Methods}

The introduction of such methods as conscious-comparative, audiolingual, and role-play promotes meaningful learning and makes the process of cultural competence formation easier. Learning foreign language comparing native and foreign language peculiarities has not only practical values but deepens knowledge, promotes respect to other peoples. Mastering language means the ability to carry on a conversation and understand spoken language. Language skills are formed through constant reviewing and remembering structures containing certain knowledge. Knowledge-based on students' interest and proved by their emotions is absorbed better. Role-play method facilitates speech activity, develops language skills, improves communication and understanding between participants; enable to solve the certain problem through discussion. Simulation of a real communication allows taking into account age and individual characteristics of its participants, increases motivation, teaches how to overcome language barriers and as a result improves learning outcomes.

\section{Participants}

There are a lot of studies focused on specialists' professional development and cultural competence development, but it is necessary to pay attention on such issues as cultural influence on the professional development, and training of specialists who are ready to work independently considering values and sociocultural peculiarities of a multicultural environment. To show the importance of cultural competence and its influence on professional development 308 students of the State Higher Educational Institution "Vasyl Stefanyk Precarpathian National University", Kryvyi Rih National University, and Dnipro University of Technology with approximately the same level of academic performance were involved in the experiment. The number of students in the experimental group equaled 158 individuals, in control one -150 . The study in the control group was conducted according to the traditional technique, whereas the students of the experimental group were trained according to the author's experimental technique of cultural competence formation. The experimental technique was based on the implementation of students' linguistic- and country-oriented studying while foreign language learning as well as on the activation of their work focused on comparing and analyzing language and cultural phenomena to ensure the development of the appropriate competence.

\section{Research Instruments}

The diagnostic and summative tests were carried out to determine the levels of formedness of cultural competence and to check the effectiveness of the methodology developed. The first group studied according to the developed methodology of formation of cultural competence based on the use of certain text material and a system of tasks and exercises aimed at finding the information about linguistic and cultural differences. The organization of the learning process according to the developed technique involves the use of pre-text, text, post-text exercises, 
dialogues, polylogues, situations, linguistic and country-oriented commentaries, which creates favorable conditions for mastering the skills of identifying those culturally-marked units, that do not coincide in different languages, and of using the culturally-colored vocabulary in accordance with both communicative situations and non-verbal means of transmitting information (Bakum et al., 2019). In terms of the second group, the traditional system of foreign language learning was used. Accordingly, the first group will be considered an experimental group (EG), the second one will be considered a control group (CG).

\section{Research Procedures}

The experimental technology involved the gradual formation of cultural competence. The main content of the work at each stage is reflected in their names: motivational-axiological, productive-creative, and reflexive-corrective.

At the motivational-axiological stage the work was carried out with 1-2-year students. Its aim was to develop positive motivation for the formation of cultural competence; to lay the foundations of a value-based attitude to future professional activity through giving value substance to concepts needs, interests, beliefs, social guidelines, professional values, ideals, corporate culture and others.

For qualitative acquisition of primary knowledge, there were used explanatory, heuristic, research, and illustrative methods, which were embodied through problem lectures, conversations, stories, demonstrations, and laboratory experiment.

At the second - productive-creative stage of teaching, during which there were formed productive and creative qualities of the students who continued their studies in the 3rd year, there were used operational, productive and creative methods (heuristic, simulation, project), that ensure the transformation of theoretical knowledge into practical experience due to the simulation of professional activities. Heuristic methods (brainstorm, theory of inventive problem solving) facilitate the development of creative thinking, imagination, nonlinear thinking and ability to overcome barriers when solving creative tasks. Simulation methods simulate the professional activity. Project method cultivates the ability to solve tasks as a result of independent cognitive activity and provides the presentation of these results. These methods were implemented in laboratory experiments, creative projects.

The main task of this stage was to expand the range of cultural concepts, increase insight into culture-congruent types of professional activities, form the ability to implement the acquired knowledge and skills in practice, and apply culture-universal knowledge.

The aim of the third-reflexive-corrective stage of training - was to form a stable idea of the process and result of professional activity as a product of culture and the need to creatively, taking into account ethical considerations, implement the acquired professional knowledge and skills. During the work with the students, there were used dialogues, training, professional simulations, methods of creative projects, control and correction. Methods of creating and resolving professional situations (case-study) involved analysis, development of practical solution and evaluation of the specific situation and facilitated professional development of students' individual psychological peculiarities to the fullest extent, placed the students in a 
position of a fellow-teacher who teaches, helps, rather then moralizes; directs, guides, not just observes. Business games, communicative, professional situations erased barriers between a teacher and a student, besides, it was not the teacher who blended in students' environment, but the students became the teacher's colleagues. In this atmosphere, professional tasks were resolved together, which created special emotional relationships in the audience, which allowed to overcome a so-called "psychological barrier of artificial communication", to get rid of stress and disturbance, anxiety.

The control and correction method considered students' correction and evaluation activity, which actualized the processes of students' self-improvement, self-education, and selfdevelopment. Individual and frontal assessment (questioning, solving of specific tasks, tests), social and psychological trainings business role-playing games were used.

Thus, the technology proposed modeled not only teacher's activity, but also students' educational and cognitive activity, which provided the necessary objectivity while implementing the technology proposed. It is important to implement this methodological complex during the entire process of specialists' training.

The basic initial requirements for the content and organization of the learning process based on the proposed technique follow from the regularities of the modern stage of the specialists' training process; they are aimed at solving the main tasks of the process. These requirements can be stated in the form of the following principles:

-interdisciplinary integration for the formation of cultural competence;

- professional orientation while organizing the learning process: studying of the humanities is determined by the system of knowledge and skills necessary to solve problems in the future specialty;

-integration of communicative and activity-based approaches to the formation of the course, which involves filling the professional component of the training process with communicative orientation;

-principle of tolerant relationships, which involves showing respect, empathy, and goodwill during discussions on solving problem situations, ability to express and substantiate own opinions;

- principle of concentric accumulation of general cultural experience while studying the disciplines of the humanities and professional cycles and its implementation in practical and professional activities (Zhumbei, 2016).

During the formation of cultural competence, various forms of work were used (individual, pair, group, collective ones); it motivated the students to consider each person's opinion and work out a personal technique of $\mathrm{Q}$ and A development since this effects successful task performance. As a result, the students gained the experience of social and professional communicative behavior.

\section{Basic Components, Tasks and Modulus of Cultural Competence Development}

The cultural competence of non-philological students while learning a foreign language is an effective means of personal development through the activation of interest in cognition, 
increased creative skills, and personal and professional enrichment. A model-project was developed that reflected the overall aim of education - the formation of cultural competence, which is a system-forming element of a holistic system of specialist training. This goal is considered to be relatively independent in the process of professional education, which is being implemented while studying a foreign language.

The model of cultural competence development is based on the introduction of the cultural approach oriented to the implementation of the ideas of the relationship between man and culture, which involves the integration of professional knowledge with cultural ones, formation of attitude to professional activity as a cultural product and the acknowledgment of the formation of the man of culture as a final result of the learning process. The competence approach as the main idea of modern education improvement is focused on students' gaining specific practiceoriented knowledge and development of personal qualities that will allow future professionals to become successful in life and professional activity. The communicative approach forms the ability to create own phrases, uses cultural aspects to eliminate obstacles during the process of communication and promote interest, makes the educational process closer to real communication.

The tasks for its achievement were determined as follows:

- to develop positive motivation for the formation of cultural competence and individual intellectual and psychological qualities of students of non-philological specialties for its implementation in professional activities;

- to form the key components of cultural competence: cognitive, moral- axiological, communicative, cultural;

- to enrich students' experience in the practice of resolving professional problems in accordance with their own and social cultural needs;

- to develop the skills of intercultural interaction for the effective implementation of tolerant communication in professional activities.

The experimental model embraced three modules of learning process: content-related, technological, resultative, the essence of which was conditioned by the regulations of cultural and competence approaches.

Consequently, the content-related module determined the content of the formation of the culture of world cognition and reflection, culture of social organization and regulation, management culture, culture of interpersonal interaction, culture of business communication, and information culture of future professionals. The task of this systemic element of the experimental model is to provide students with knowledge about the connections between separate branches of scientific knowledge based on intercultural interaction.

Technological module outlined the stages and relevant traditional and innovative means of implementing the content of education. The task of this module is to provide subject-subject relations between teachers and students during gradual formation of cultural competence, to form the experience of intercultural interaction. 
Resultative module contained criteria and indicators, characteristics of levels of cultural competence of future specialists. Its task is to provide tools for diagnosing the final results of the process of formation of cultural competence.

Creating the model the following factors that indicate the person's future behavior were taken into account. They are values (encourage to be active and creative), nature of the activity, attitude to the environment, experience, customs and traditions. The following structure of the cultural competence during the professional training of students of non-philological specialties in the process of studying a foreign language has been determined:

- cognitive component represents the culture of understanding and representation of the world. It is based on the specialist's knowledge about science, religion, art;

- moral-axiological component is based on the culture of social organization and regulations, managerial culture, the culture of interpersonal interaction;

- communicative component involves the culture of the business relationship, developed information culture to use it during the professional activities;

- cultural component is the understanding of the importance of the language as a cultural code of a nation, understanding of verbal and non-verbal peculiarities to interpret the message accurately, understanding of culture and values of other people during the process of communication.

\section{Criteria, Parameters and Indicators of Cultural Competence}

To define the components of the cultural competence of non-philological specialties students in the process of studying foreign language criteria, parameters and indicators were used.

The criteria of the cognitive component comprise the following parameters: skills in searching, processing, and analyzing the information from different sources; creative use of the information with respect to cultural aspects of the professional situation, ability to self-education and self-development, understanding the value of professional and cultural knowledge in professional activity. The indicators of the cognitive component involve: ability to use information from the Internet resources; to process different literature resources; to use computer technology for information processing; to use cultural information creatively in the context of professional training; to create a cultural-based product of the professional activity; to search information for improving one's personal level and level of professional and cultural skills; attitude to templates in professional activity.

The culture of social adaptation and regulation, managerial culture and culture of interpersonal interaction are criteria of the moral-axiological component. Among the parameters of moral-axiological component of the cultural competence are attitude to different styles of organization, management, and leadership, ability to form a friendly socio-psychological environment among the staff to solve professional tasks effectively, behavioral, emotional, and communicative components. The indicators of the moral-axiological component are the following abilities: to identify the main goals of business activity, to interact within the group, to determine the success criteria, to facilitate the self-development of others, to apply a creative approach to solve unusual tasks, to cultivate the relationship. 
Arab World English Journal (AWEJ) Volume 12. Number 4. December 2021

Cultural Component in Professional Development

Bakum, Savchak, Kostiuk, Zhumbei \& Poznanskyy

Among the criteria of communicative component, the culture of business interaction and information culture were determined. The following parameters have been determined within the communicative component: readiness to communicate, communicative tolerance, language and speech skills, non-verbal behavior, ability to improve the language level, ability to accumulate and share the professional and socio-cultural experience. The key indicators of the communicative component are: understanding other cultures, tolerance to any partners in any situations, ability to use information resources effectively, demonstrating the knowledge of a language and other communicative systems during the process of communication, and understanding that language is crucial for professional development.

The culture of international communication and understanding of the linguistic view of the world is the criteria of the cultural component. Its parameters are: the development of the value attitude to the representatives of other cultures, knowledge of physiological, psychological, and social features of interlocutors, positive attitude towards the cultural values and norms of different nations, respectful attitude towards history, culture, and values of other people. The indicators of the cultural component are: knowledge of native and other cultures, understanding of the potential of language in the process of intercultural communication to achieve the results; ability to analyze the differences of culture-specific words of foreign and native languages, ability to compose sentences using idioms and proverbs.

Creating the model the following principles have been taken into account: communicative (creation of situations of real communication, development of a social, educational, cognitive, professional, and moral relationship and transformation of formed skills to life), professionally-oriented (development of successful professional communication skills), domination of problematic cultural tasks (use of knowledge of native and foreign languages to prevent cultural conflicts during the communication process with unknown culture). The experimental technology involved the gradual formation of cultural competence.

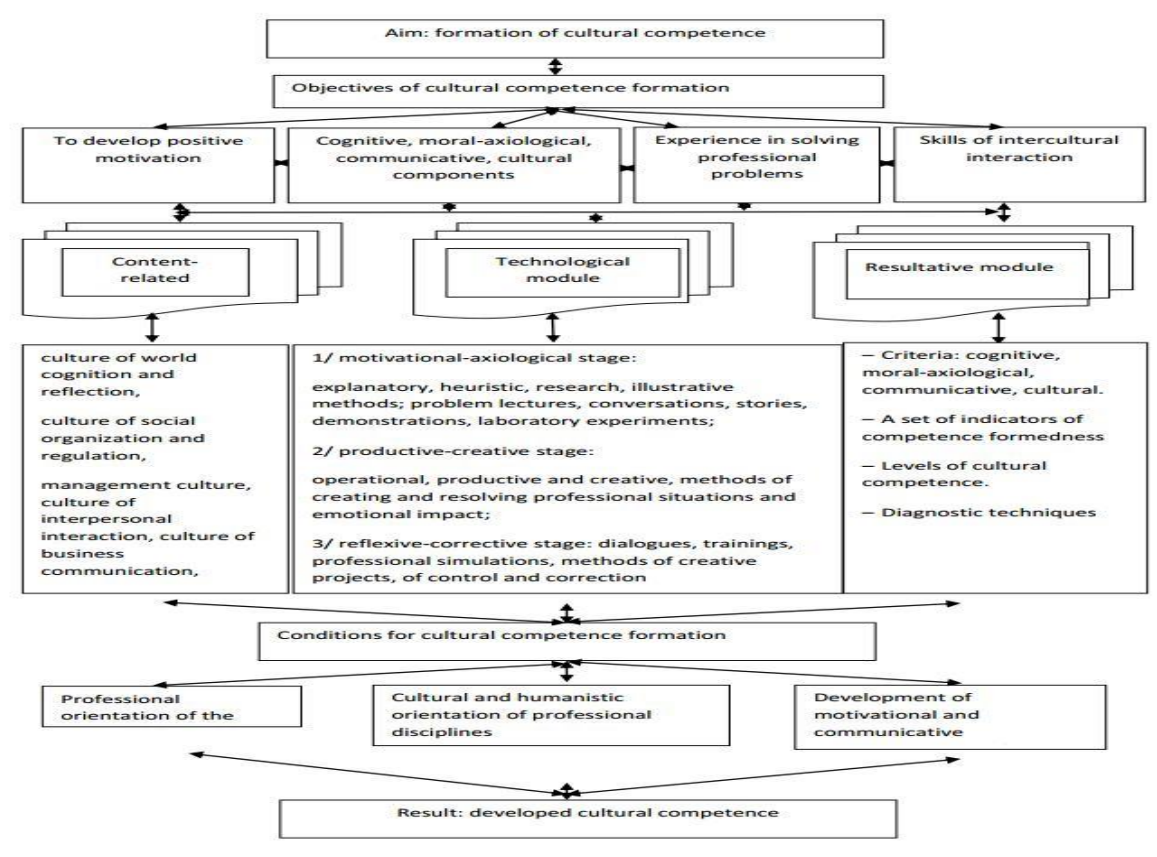

Figure 1 Structural-functional model of formedness of cultural competence of students of nonphilological specialties 


\section{Findings}

The research paper shows that there is a lack of understanding of the cultural influence on professional development. So, the given model of the cultural competence of students of nonphilological specialties has become methodological guidance both in the process of students' professional training aiming at outcomes of learning and in the process of diagnostics of students' readiness to the implementation cultural competence into the professional activity. During the experiment students' cultural dimension has changed. They indicated the need for the cultural enrichment of the material of philological disciplines and professional subjects as well.

Cultural enrichment has contributed to the development of positive motivation to the development of cultural competence and has become the basis of value-based attitude towards future professional activity and made the understanding of culture deeper.

After the experiment completion, the quantitative and qualitative changes in the levels of formedness of the components of cultural competence were specified. To identify the levels of formedness of the cognitive component of cultural competence, there was used the test (assessment of the effectiveness of cross-cultural interaction and potential adaptability in cultural diversity by L. Van Dyne, S. Eng in A. Solodka adaptation) (Solodka, 2015) which made it possible to analyze thinking strategies for intercultural interaction, motivation for intercultural interaction, attitude to representatives of other cultures, effectiveness of the interaction and adaptation to a foreign cultural environment. Tables 1, 2, 3, 4 below show the level of formedness of the different components of cultural competence at the ascertaining and control stage.

Table 1. Level of formedness of the cognitive component of cultural competence at the ascertaining and control stages

\begin{tabular}{|c|c|c|c|c|}
\hline \multirow{2}{*}{ Stage } & \multirow{2}{*}{ Group } & \multicolumn{3}{|c|}{ Level } \\
\cline { 3 - 5 } & & Insufficient, \% & Sufficient, \% & High, \% \\
\hline \multirow{2}{*}{ Ascertaining } & \multirow{2}{*}{ EG } & 43.7 & 43.7 & 12.6 \\
\cline { 2 - 5 } & CG & 38.7 & 42.0 & 19.3 \\
\hline \multirow{2}{*}{ Control } & EG & 20.3 & 47.5 & 32.2 \\
\cline { 2 - 5 } & CG & 38.0 & 45.3 & 16.7 \\
\hline
\end{tabular}

Thus, the test results indicate that $20.3 \%$ of the EG students demonstrated the insufficient level of formedness of the cognitive component of cultural competence, the CG students demonstrated $38.0 \%$; the sufficient level of formedness was shown by $47.5 \%$ of the EG students, and by $45.3 \%$ of the CG students; the high level of formedness was demonstrated by $32.2 \%$ of the EG students and by $16.7 \%$ of the CG students.

The levels of formedness of the moral-axiological component of cultural competence were determined by using the questionnaire for tolerance estimation (Magun et al., 2003). The purpose of the questionnaire is to identify the types of tolerant attitudes to the representatives of other nations, cultures, and views. 
Arab World English Journal (AWEJ) Volume 12. Number 4. December 2021

Cultural Component in Professional Development

Bakum, Savchak, Kostiuk, Zhumbei \& Poznanskyy

Table 2. Level of formedness of the moral-axiological component of cultural competence at the ascertaining and control stages

\begin{tabular}{|l|l|c|c|c|}
\hline \multirow{2}{*}{ Stage } & \multirow{2}{*}{ Group } & \multicolumn{3}{|c|}{ Level } \\
\cline { 3 - 5 } & & Insufficient, \% & Sufficient, \% & High, \% \\
\hline \multirow{2}{*}{ Ascertaining } & \multirow{2}{*}{ EG } & 30.4 & 58.9 & 10.7 \\
\cline { 2 - 5 } & CG & 36.7 & 56.7 & 6.6 \\
\hline \multirow{2}{*}{ Control } & EG & 15.8 & 58.9 & 25.3 \\
\cline { 2 - 5 } & CG & 36.7 & 52.7 & 10.6 \\
\hline
\end{tabular}

The test results indicate that $15.8 \%$ of the EG students showed the insufficient level of formedness of the moral-axiological component of cultural competence, $58.9 \%$ of the students showed the sufficient level of formedness, and $25.3 \%$ of them showed the high one. Alternatively, $36.7 \%$ of the CG students demonstrated the insufficient level of formedness of the moral and value component of cultural competence, $52.7 \%$ of the students demonstrated the sufficient level of formedness, and $10.6 \%$ of them demonstrated the high one.

Table 3. Level of formedness of the communicative component of cultural competence at the ascertaining and control stages

\begin{tabular}{|l|l|c|c|c|}
\hline \multirow{2}{*}{ Stage } & \multirow{2}{*}{ Group } & \multicolumn{3}{|c|}{ Level } \\
\cline { 3 - 5 } & & Insufficient, \% & Sufficient, \% & High, \% \\
\hline \multirow{3}{*}{ Ascertaining } & \multirow{2}{*}{ EG } & 24.7 & 58.2 & 17.1 \\
\cline { 2 - 5 } & CG & 32.0 & 56.0 & 12.0 \\
\hline \multirow{3}{*}{ Control } & EG & 12.7 & 58.2 & 29.1 \\
\cline { 2 - 5 } & CG & 28.7 & 59.3 & 12.0 \\
\hline
\end{tabular}

The diagnostics of levels of formedness of the communicative component of cultural competence involved performing of the appropriate exercises by the students. The formedness of the communicative component of cultural competence at the insufficient level was found from $12.7 \%$ of the EG students and $28.7 \%$ of the CG students; at the sufficient level, it was specified in $58.2 \%$ of the EG students and $59.3 \%$ of the CG students; at the high level, it was found from $29.1 \%$ of the EG students and $12.0 \%$ of the CG students.

Table 4. Level of formedness of the cultural component of cultural competence at the ascertaining and control stages

\begin{tabular}{|l|l|c|c|c|}
\hline \multirow{2}{*}{ Stage } & \multirow{2}{*}{ Group } & \multicolumn{3}{|c|}{ Level } \\
\cline { 3 - 5 } & & Insufficient, \% & Sufficient, \% & High, \% \\
\hline \multirow{2}{*}{ Ascertaining } & EG & 30.4 & 58.2 & 11.4 \\
\cline { 2 - 5 } & & & 59.3 & 6.7 \\
\hline \multirow{2}{*}{ Control } & EG & 34.0 & 55.7 & 28.5 \\
\cline { 2 - 5 } & CG & 15.8 & 60.0 & 8.7 \\
\hline
\end{tabular}

The determination of the levels of formedness of the cultural component of cultural competence involved the use of the "Determination of the level of cross-cultural competence" methodology (Solodka, 2015). The results of the corresponding survey indicated that $15.8 \%$ of the EG students 
have the insufficient formation level of the cultural component of cultural competence, $55.7 \%$ of the EG students have the sufficient level, and $28.5 \%$ of them have the high level. In terms of the control group, $31.3 \%$ of the students have the insufficient level of formedness of the cultural component of cultural competence, $60.0 \%$ have the sufficient level, and $8.7 \%$ have the high one. The dynamics of formedness of cultural competence at different stages of the experiment is presented in the bar chart.

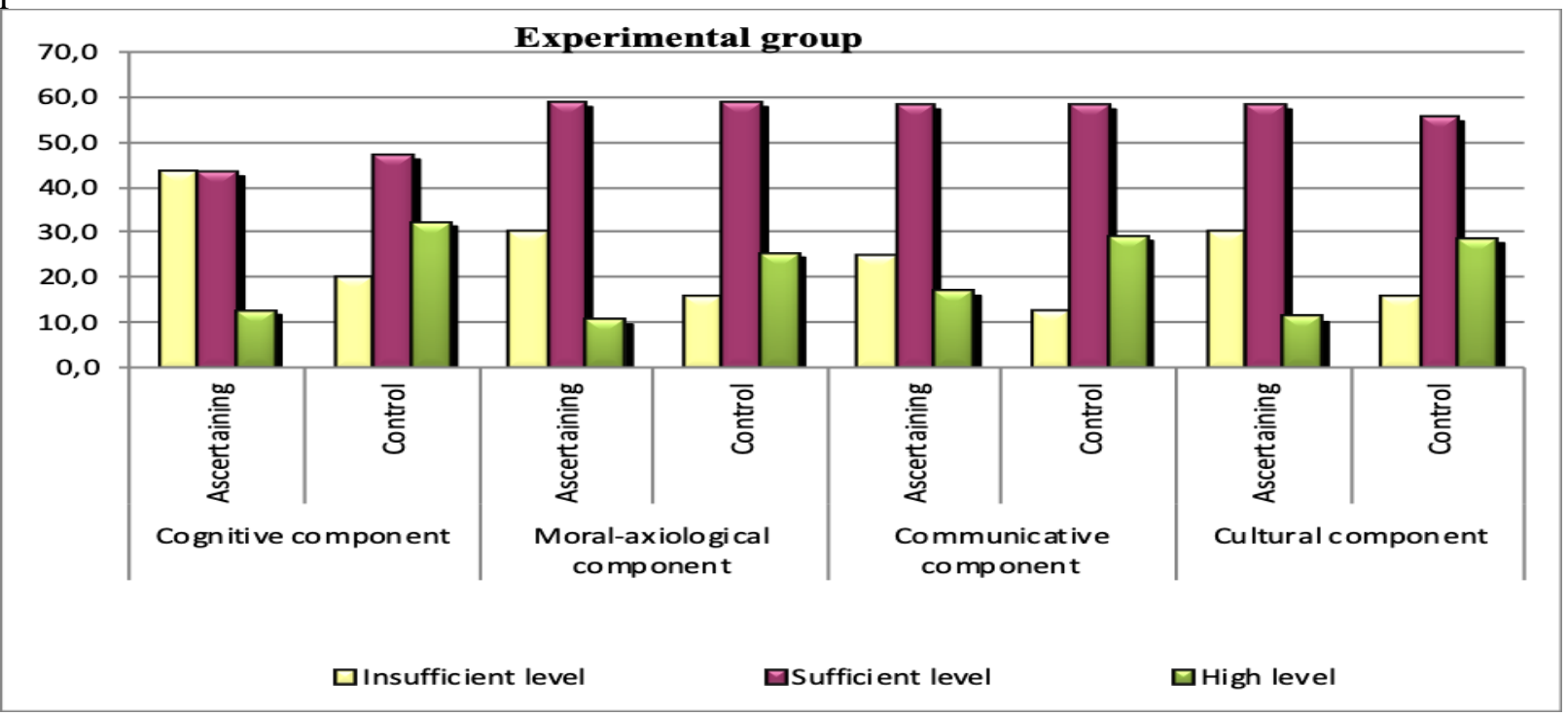

Figure 2. Dynamics of the percentage values of the number of EG students with the insufficient, sufficient, and high levels of formedness of cultural competence at the ascertaining and control stages of the experiment.

\section{Discussion}

The study aimed to determine the main components and formation conditions of cultural competence, promote the interest in learning, personal and professional enrichment. The analysis of the results, based on four criteria (cognitive, moral-axiological, communicative, cultural), demonstrated the following outcomes: learners have started to understand the necessity of cultural enrichment of disciplines; it has increased the perception of other culture and language as well; learning the language on cultural basis develops skills which are in demand in the professional activity; the necessity to integrate professional knowledge with cultural ones.

The research defined the main components of cultural competence during the professional training of students: cognitive (represents the culture of understanding and representation of the world); moral-axiological (based on the culture of social organization and regulations, managerial culture, culture of interpersonal interaction); communicative (involves the culture of the business relationship, developed information culture to use it during the professional activities); cultural (comprises the understanding of the importance of the language as a cultural code of a nation). The findings correlate with that of Fedortsova (2016).

The study findings consistent with the ideas of Liddicoat \& Scrino (2013) that the cultural development of future specialists during the language learning increases their mobility and competitiveness on the labour market as well. 
The results of the research support the Modeer's (1999) idea that cultural proficiency, communication skills and cooperation are the key features of modern specialists.

The study shows that the development of cultural competence during language learning forms positive motivation improves intellectual and professional qualities; enriches students' experience in the practice of resolving professional problems in accordance with their own and social-cultural needs; develops skills of intercultural interaction for the effective implementation of tolerant communication in professional activities.

\title{
Conclusion
}

The study aimed to examine how the development of cultural components in the process of learning language affects the formation of professional qualities. The research defined the model of cultural competence formation of non-philological specialties based on the cultural approach which involves the integration of professional knowledge with cultural ones, understanding of professional activity as a cultural product and the acknowledgment of the formation of the man of culture as a final result of the learning process. The development of all components (cognitive, moral-axiological, communicative, cultural) promoted the ability to interact with the representatives of other cultures; prevent conflicts in the interpersonal and professional fields; understand the equality of cultures; determine the success or failure of a communication act. The obtained results make it possible to state that the proposed model of the formation of cultural competence of the students of non-philological specialties and the technique developed on its basis certify its effectiveness. It proved the possibility to improve professional skills which are necessary for future specialists by means of culture.

\begin{abstract}
About the Authors
Zinaida Bakum, Doctor of Science (Pedagogics), Professor of Department of Ukrainian Language at Kryvyi Rih State Pedagogical University, Kryvyi Rih, Ukraine. Her main areas of interest include applied linguistics and cross-cultural approach to the process of teaching languages. https://orcid.org/0000-0001-8357-6168
\end{abstract}

Iryna Savchak, Associate Professor of the Department of Foreign Languages and Translation, Vasyl Stefanyk Precarpathian National University, Ivano-Frankivsk, Ukraine. Her academic interest is in the field of methods of teaching languages, and culture study. http://orcid.org/0000-0003-0326-5779

Svitlana Kostiuk, Associate Professor of the Department of Foreign Languages, Kryvyi Rih National University, Kryvyi Rih, Ukraine. Her academic interests include methods of teaching languages, and intercultural competence. http://orcid.org/0000-0002-3587-4483

Marianna Zhumbei, Associate Professor of the Department of Foreign Languages and Country Studies, Vasyl Stefanyk Precarpathian National University, Ivano-Frankivsk, Ukraine. Her academic interest is in the field of foreign languages training, cultural competence, and multilingualism. http://orcid.org/0000-0002-8883-4135

Roman Poznanskyy, Associate Professor of the Department of Foreign Languages and Country Studies, Vasyl Stefanyk Precarpathian National University, Ivano-Frankivsk, Ukraine. His academic interest is in the field of linguistics, university education in Ukraine, Great Britain, and the USA. http://orcid.org/0000-0003-0540-6977 
Arab World English Journal (AWEJ) Volume 12. Number 4. December 2021

Cultural Component in Professional Development

Bakum, Savchak, Kostiuk, Zhumbei \& Poznanskyy

\section{References}

Ait Haddouchane, Z., Bakkali, S., Ajana, S., \& Gassemi, K. (2017). The application of the competency based approach to assess the training and employment adequacy problem. International Journal of education (IJE), 5(1), 1-18. Retrieved from: https://arxiv.org/ftp/arxiv/papers/1704/1704.04985.pdf-

Bakum, Z., \& Palchykova, O. (2019). Teaching foreign languages on the cross-cultural bases. Scientific bulletin of Kryvyi Rih state pedagogical university. Philological studies, 19, 129-145.

Bakum, Z., Palchykova, O., \& Kostiuk, S. (2019). Teaching foreign languages: cross-cultural approach. Ternopil: Osadtsa.

Blahodietielieva-Vovk, S. (2009). Complex model of a human in the process of application of civilized approach in Economy. Proceedings of Scientific Works of Cherkasy State Technological University Series Economic Sciences, 24, 45-50.

Common European Framework of Reference for Languages: Learning, Teaching, Assessment, Language Policy Unit (2001). Strasbourg. Retrieved from: www.coe.int/lang-CEFR.

Fedortsova, O. (2016). The development of cultural competence of future power engineers in the process of humanitarian discipline learning. (Thesis for a candidate Degree in Pedagogy). Zhytomyr Ivan Franko State University, Ukraine. Retrieved from: http://eprints.zu.edu.ua/20476/1/dys_Fedorcova.pdf .

Fierro, I., Pico, M., Cardona, D. (2018). The impact of intercultural competencies in the society's education index and how it affects productivity. Revista Espacios, 39(40), 5-9. Retrieved from: http://www.revistaespacios.com/a18v39n40/18394005.

Hrechanyk, N. (2020). Theoretical basis of culture oriented environment for culture competence development of future primary school teachers: Pedagogy in modern conditions: collective monograph. Boston: Primedia eLaunch. DOI10.46299/ISG.2020.MONO.PED.III.

Ivanov, A. (2016). The role of cultural environment of educational organization in children's acquisition of spiritual values. Pedagogical education in Russia, 3, 198-205.

Jeannotte, M. Sh. (2017). The social effects of culture: a literature review. Centre on Governance (University of Ottawa). DOI:10.13140/RG.2.2.15680.84482. Retrieved from: https://socialsciences.uottawa.ca/governance/sites/socialsciences.uottawa.ca.governance/f iles/social_effects_of_culture-final.pdf

Kochneva, L, Zulfugarzade, T., Aleksandrova, N., et al. (2018). Humanitarian component of professional training as factor of increasing student cultural level Revista espacios, 39(17), 23-34. Retrieved from: https://www.revistaespacios.com/a18v39n17/18391723.html.

Kovalchuk, V., \& Fedorchenko, M. (2018). Introduction of competence-based approach to the professional training of pedagogical students. Young scientist, 11(63), 675-678.

Liddicoat, A. \& Scrino, A. (2013). Intercultural Language Teaching and Learning. New York: Wiley-Blackwell.

Magun, V., Zamkochyan, M., \& Magura, M. (2003). Questionnaire for tolerance measurement. Practical course on psychological diagnostics and tolerance research. Moscow: MSU.

Melnyk, V. (2016). Anthropological foundations of culture as a basis of human variety in terms of the reconfiguration of the global space. Humanitarian Bulletin of Zaporizhzhe State Engineering Academy, 65, 186-201. Available at: znpgvzdia_2016_65_20.pdf. 
Modeer, C. (1999). Competence demands for today and tomorrow: quality progress through interaction with industry. Mobillising Human Resources for Innovation. Proceedings from the OECD Workshop on science and technology Labour Market, DSTI/STP/TIP (99)2, 211-216. Retrieved from:

https://www.oecd.org/officialdocuments/publicdisplaydocumentpdf/?cote=DSTI/STP/TI $\mathrm{P}(99) 2 /$ FINAL\&docLanguage $=$ En

Opachko, M. (2017). Culture based approach in the formation of management competence of teachers. Scientific bulletin of Uzhgorod university Series "Pedagogy. Social Work”, 1 (40), 197-201.

Palamar, S. (2018). Competence approach as a methodological landmark of modernization of modern education. Educational Discourse, 2-3(20-21), 267-278. Retrieved from: http://elibrary.kubg.edu.ua/id/eprint/23964/1/Palamar_S_P\%20PPD_PI_2018.pdf.

Panfilov, Yu., \& Furmanets, B. (2017). Competency based approach in education: experience, problems, prospects. Theory and Practice of Social Systems Management, 3, 55-67. Retrieved from: http://tipus.khpi.edu.ua/issue/view/6670.

Shutenko, A., Shutenko, E., Sergeev, A., \& Ryzhkova, I. (2018). Socio-cultural Dominants of Higher School Innovation Mission. Revista Espacios, 39(52), 34-41. Retrieved from: http://www.revistaespacios.com/a18v39n52/18395234.html

Slastenin, V. (1997). Pedagogy: innovation activity. Moscow: Magistr.

Solodka, A. (2015). Theoretical and methodological bases of cross-cultural interaction of participants of educational process in the higher educational establishments. (Doctoral thesis). Mykolayiv National University named after V. Sukhomlynskyi, Ukraine.

Standards of higher education of Ukraine. (2019). Retrieved from: https://mon.gov.ua/ua/osvita/visha-osvita/naukovo-metodichna-rada-ministerstva-osviti-inauki-ukrayini/zatverdzheni-standarti-vishoyi-osviti

Telychko, N., \& Kostiuk, M. (2019). The peculiarities of multicultural competence development of future artists in the educational foreign environment. Scientific bulletin of Mukachevo State University Series “Pedagogy and Psychology”, 1(9), 164-168. DOI 10.31339/24133329-2019-1(9)-164-167To=

The Council of Europe Contribution to the European Higher Education Area 2018-2020. (2019). Bologna follow up group. Helsinki.

UNESCO Guidelines on Intercultural Education. (2006). Printed at UNESCO in Paris (ED2006/WS/59) - CLD 29366.

Zhumbei, M. (2016). Development of culture-universal competence of future travel managers while professional training. (Thesis for a candidate Degree in Pedagogy). Vasyl Stefanyk Precarpathian National University, Ukraine. Retrieved from: http://irbisnbuv.gov.ua/ASUA/1079369.

Zyryanova, S., Chesnokova N., Shtanko M., \& Dubareva M. (2020). The link between language and culture on the lessons of Russian as a foreign. Amazonia Investiga, 9 (28), 421-426. Retrieved from: https://amazoniainvestiga.info/index.php/amazonia/article/view/1337. DOI: http://dx.doi.org/10.34069/AI/2020.28.04.47. 